performances (weaning-oestrus, weaning-conception and farrowing-conception intervals) as well as the size and weight of the litter, were recorded at different ages (Io, 35 and 63 days).

Early weaning (I 2 days) did not change either the mean interval between weaning and oestrus (I 3.4 days versus 12.5 after classical weaning) or the weaning conception interval (22.7 versus 2 r. 6 days). However, these intervals involving all available data showed a very strong intra-treatment variability ( 100 to $150 \mathrm{p}$. Ioo). Only the percentage of sows exhibiting oestrus within 8 days following weaning varied significantly (54.6 versus $64.5 \mathrm{p}$. Ioo in favour of the latest weaning). In addition, weaning at $\mathbf{I} 2$ days did not affect the age at puberty of the females : age at Ist farrowing was 363 and 374 days, respectively after early and classical weaning.

Weaning at 12 days led, on an average, to a significant decrease of litter size in our cxperiment although the great variability of this criterion (standard deviation : \pm 2 piglets per litter) did not allow to observe such a difference in all successive litters. The reduction represented about 0.4 per litter at birth and 0.3 at weaning, but no linear relationships was observed between farrowing-conception length and size of the following litter. Likewise, a lowering of the mean weight of the piglets was observed at 63 days after early weaning and rearing in batteries but this was probably due to the fact that the farmers were not sufficiently accustomed to the weaning technique. However, the overall feed efficiency was improved by 15 p. Ioo consecutively to weaning at 12 days.

In practise, weaning at $\mathrm{I} 2$ days leads to :

- an increase of 0.32 litter/sow and per year;

-- an increase of 1.4 piglet/sow and per year, the variation being +0.2 to $3 . \mathrm{I}$ piglet according to herds.

This experiment shows that in the light of present knowledge the minimum age for weaning of piglets is located around $\mathrm{I} 2$ days; below that age both reproductive performances of the sow and growth of the young animals might be disturbed.

\title{
Nitrogen balance as affected by introduction of protein from unicellular organisms into diets of piglets weaned at 3 weeks
}

\author{
B. SEVE \\ Station de Recherches sur l'Élevage des Porcs, I. N. R. A., C. N. R. Z., \\ 78350 Jouy en Josas
}

In this trial conducted on 30 piglets maintained in metabolism crates between 21 and 63 days of age, we compared the effects of incorporating alkane yeasts $(\mathrm{GFP})^{1}$ or bacterial proteins (ICI) ${ }^{2}$ into weaning diets on growth and nitrogen metabolism. The protein supply of the control diet included barley (30 p. 100) and a mixture of skim-milk (15 p. Ioo), Norwegian herring meal (9.3 p. 100) and soyabean meal (13.4 p. 100). Two types of alkane yeast prepared with (B) or wi-

(1) Groupement Firançais des Protéines.

(a) Imperial Chemical Industry Ltd. 
thout (A) heat treatment before drying, were studied. In the first three experimental diets (LA, $I, B, P B)$ herring protein was replaced by $A, B$ yeasts and bacterial proteins, respectively. $\Lambda t$ a second level of incorporation into the diet, the proteins from unicellular organisms replaced in acldition the soyabean meal of the control diet $\left(\mathrm{LI}_{2}\right.$ and $\left.\mathrm{PB}_{2}\right)$. Sulphur amino acid levels were equalized by supplementation with synthetic DL-methionine. Daily mean gains (g/day) (T) : $269-\left(\mathrm{LA}_{1}\right): 26 \mathrm{I},\left(\mathrm{L}_{1}\right): 269,\left(\mathrm{~PB}_{1}\right): 248-\left(\mathrm{LB}_{2}\right): 270,\left(\mathrm{~PB}_{2}\right): 270$ and feed conversion ratios $(\mathrm{g} / \mathrm{g})-(\mathrm{T}): \mathrm{I} .32 \ldots\left(\mathrm{LA}_{1}\right):$ I.3O, $\left(\mathrm{LB}_{1}\right): 1.29,\left(\mathrm{~PB}_{1}\right):$ I.4.3- $\left(\mathrm{LB}_{2}\right):$ I.29, $\left(\mathrm{PB}_{2}\right):$ I.29 were not significantly affected by the experimental treatments. Heat treatment of the yeast significantly improved the apparent digestibility of nitrogen ( $\mathrm{I}: 85.7$, L. $\mathrm{A}_{1}: 86 . \mathrm{I}$ and $\mathrm{LB}_{1}: 88.2$ ). We also observed a rise in the apparent digestibility of protein when bacterial proteins replaced those of soyabcan meal $\left(\mathrm{Pl}_{1}: 86.2\right.$ versus $\left.\mathrm{PB}_{2}: 88.0\right)$. The nitrogen balances $(g \mathrm{~N}$ retained/day $) \cdots(\mathrm{T})$ : $9.32-\left(\mathrm{LA}_{1}\right): 9.07-\left(\mathrm{LB}_{1}\right): 9.27,\left(\mathrm{~PB}_{1}\right): 8.49--\left(\mathrm{LB}_{2}\right): 9.53,\left(\mathrm{~PB}_{2}\right): 9.52$ - showed that replacement of herring proteins by bacterial proteins $(-\cdots 0.83 \mathrm{~g} / \mathrm{day})$ associated with the presence of soyabean meal in the diet had a depressing effect. On the other hancl, alkane yeast proteins (A or B) seemed to be as well used as herring proteins. However, although the effects of the treatments on the retention coefficient of the nitrogen absorbed were parallel to those obtained on the nitrogen balance for the overall experimental period, a significant inferiority was noted for diet $\mathrm{LA}_{1}$ during the initial period (28-35 days) with a $\mathrm{NRC}$ of 50.3 versus $60 . \mathrm{I}$ and 62.6 , respectively for diets $T$ and $L_{1}$. The amounts of allantoin excreted : $(T): 102-\left(\mathrm{LA}_{1}\right): 138,\left(\mathrm{LB}_{1}\right): 137,\left(\mathrm{PI}_{1}\right)$ : $29 \mathrm{r}-\left(\mathrm{LB}_{2}\right): 467$ were proportional to the amounts of nucleic acid ingested, but they clid not account for the whole amount of puric nitrogen consumed.

\title{
IV. - Physiology OF REPRODUCTION
}

\section{Quantitative variations \\ of male pig plasma testosterone from birth to adulthood}

\author{
Nicole MEUSY-DESSOLLE \\ Station centrale de Physiologie animale, I. N.R.A., C.N.R.Z., \\ 78350 Jouy en Josas
}

Peripheral venous blood level of testosterone in the newborn piglet shows a large rise after birth with a maximum level between clays 5 and 17 . Except for a peak between days 35 and 45 . values decreased regularly during the first six weeks, then stayed low during the third month. From the fourth to the sixth month, testosterone level progressively increased (onset of puberty). After a larger rise between 180 and 200 days (period when sexual behavior begins), testosterone plasma level increased to reach aclult values. According to these observations, the anclrogenic function in pig presents some analogy with man. 